\title{
Coping with stress and quality of life in women with stress urinary incontinence
}

\author{
Jolanta Adamczuk ${ }^{1}$, Katarzyna Szymona-Pałkowska², Jacek Marcin Robak ${ }^{3}$, Katarzyna Rykowska-Górnik ${ }^{4}$, \\ Stanisława Steuden², Janusz Jacek Kraczkowski ${ }^{3}$
}

${ }^{1}$ SP ZOZ Nałęczów - private practice, Nałęczów, Poland

${ }^{2}$ Department of Clinical Psychology, The John Paul II Catholic University of Lublin, Lublin, Poland

${ }^{3}$ Department of Obstetrics and Pathology of Pregnancy, Medical University of Lublin, Lublin, Poland

${ }^{4} \mathrm{NZOZ}$ Zdrowie Radzyń Podlaski - private practice, Radzyń Podlaski, Poland

\begin{abstract}
Introduction: Urinary incontinence (UI) involves uncontrolled leakage of urine through the urethra as a result of damage to its sphincter muscle and a disturbed function of the urogenital diaphragm within the pelvis minor. The symptoms of UI radically impair psychological, somatic, and social functioning. The aim of each disease stress coping process is to reduce the impact of harmful agents as well as the acquisition of necessary preventive measures in order to combat the disorder. Aim of the study was to assess the relationship between coping styles used when dealing with stress associated with disease and the quality of life.

Material and methods: The study was carried out at an outpatients' clinic located in the Lublin Province (eastern Poland), covering 150 women with diagnosed stress urinary incontinence, aged between 32 and 79. The following methods were used: (a) Coping Inventory for Stressful Situations (Endler, Parker) to assess coping styles, (b) CASP-19 scale (Higgins, Hyde, Wiggins, Blade) to measure the overall quality of life, and (c) Urinary Incontinence Life Quality Scale (Szymona-Pałkowska, Kraczkowski).

Results: The preferred style in the studied group of women was Task-Oriented Coping. This style is associated with a low score on the Independence from Symptoms scale and low Control, being simultaneously correlated with Autonomy and Self-Realisation. Emotion-Oriented Coping is associated with low psychological, physical and social well-being, as well as with little independence from the disease symptoms, little pleasure and self-realisation, but it gives a sense of internal control. Avoidance-Oriented Coping does not significantly correlate with any of the Overall Quality of Life dimensions.

Conclusions: Women suffering from UI tend to try to solve their problem by means of cognitive transformation. In their situation, clinging to the problem turns out to be a depressing factor and entails a lower quality of their life.
\end{abstract}

Key words: stress coping styles, life quality, urinary incontinence.

\section{Introduction}

Urinary incontinence (UI) is defined as involuntary passage of urine through the urethra, the symptoms depending on the type of the disease [1-4].

Generally, observations and statistical data reveal that over 50 per cent of women experience UI symptoms in their lifetime. Various symptoms of urinary incontinence should be regarded as markers of a social disease since they apply to more than $5 \%$ of the population [5].

Urinary incontinence is one of the most widespread chronic diseases, posing a social problem. Based on its symptoms and causes, several types of UI are distinguished: stress incontinence, urge incontinence, mixed incontinence, overflow incontinence, and neurological incontinence $[2-4,6,7]$. Urinary incontinence can occur even at a young age, though it affects mainly the elderly, especially women. Although the disease does not present a life threat, the sphere it concerns is delicate in its nature [3]. Apart from a disagreeable sensation of uncontrolled urine leakage, sufferers are confronted with a disagreeable odour. The intimate nature of the symptoms and their adverse effect on daily functioning imposes a significant mental burden both on the sufferers and their partners, "causing the frustration of many psychological, social and existential needs" [8, p. 132] affecting their sexual activity $[9,10]$.

Every somatic disease involves particular symptoms (alarming changes in the body, such as pain or restriction of activity), making patients modify their life plans. 
This necessity can become a source of psychological stress. The experience of stress is not an automatic response of the body to a harmful agent (disease) but rather a unique relationship between the appraisal of a particular situation on the one hand and available resources and capabilities of an individual on the other. A stress relationship implies a disturbed balance between requirements and the possibility to fulfil them [11]. According to the definition, the intensity of perceived stress will be influenced by individual abilities of a person who is confronted with a given situation. A major role is typically played by personality traits such as temperament, emotional integrity, preferred stress-coping styles, knowledge, intellectual abilities, and the burden of individual experiences - all in relation to a disease. Research to date on stress profiles connected with various clinical conditions indicates that the effectiveness of adaptation depends on the ability to adjust one's ways of coping with the nature of disease, and the outcome of stress confrontation depends more on coping than the actual impact of the stressor. The former is the "degree to which a person perceives threat in the situation" while the latter is "the perception of personal and social resources that may be used to deal with the situation" [12, p. 346] An analysis of empirical data concerning coping with disease substantiates a claim that people who perceive a disease as a stressful event (distress) manifest far more different coping strategies than those who do not have a sense of distress [13-15]. Such observations show that a large percentage of people do not perceive any threat even when somatic problems are intense $[14,16]$. It has been accepted that the best way to deal with disease stress is to use styles focused on solving a problem. This implies a greater knowledge of the disease and performing various activities intended to bring recovery or minimize the medical problem. Nevertheless, results of studies on some medical conditions, such as chronic obstructive pulmonary disease, indicate that using problem-oriented coping strategies was associated with depressive symptoms [17]. Pathological changes exert influence on the entire psychosocial condition of the patient. Due to its specific nature, each disease can activate different resources, evoke stress and trigger different strategies to cope with it. The World Health Organization defines quality of life as an individual's perception of their position in life in the context of the culture and value systems in which they live, in relation to their goals, expectations, standards, and concerns. It is a broad-ranging concept affected in a complex way by the person's physical health, psychological state, level of independence, social relationships, and their relationships to salient features of the environment" [18, p. 1].

The aim of the study was to analyse ways of coping with stress as used by women with urinary inconti- nence and appraise the relationship between the styles used and life quality indicators.

\section{Material and methods}

The study covered 150 patients of outpatients' clinic (SP ZOZ) in the town of Nałęczów, eastern Poland, aged 32-79, who were initially diagnosed with stress UI. The mean age was 53.4. The following methods were used: (a) Coping Inventory for Stressful Situations (CISS) [19] to assess coping styles, (b) CASP-19 measure [20] to measure the overall quality of life, and (c) Urinary Incontinence Life Quality Scale [21].

In order to determine the severity of the incontinence, urodynamic tests were performed, including cystometry, urethral pressure profilometry (while resting and coughing), and uroflowmetry.

Coping Inventory for Stressful Situations distinguishes three styles of coping with stress:

Task-Oriented Coping, when a person focuses on a problem and tries to find a solution. The main aim is to improve the life situation by removing the source of stress.

Emotion-Oriented Coping, when a person focuses on themselves and their own emotions. This sort of attitude serves to lower emotional tension, yet occasionally it can contribute to an elevated degree of tension and lowered mood.

Avoidance-Oriented Coping, which characterizes people who have a tendency to avoid thinking of a difficult situation. They can engage is substitute activities, such as thinking of pleasurable things, excessive sleeping, overeating, or seeking social contact [19].

The Urinary Incontinence Life Quality Scale, designed by Szymona-Pałkowska and Kraczkowski, measures the quality of life of women suffering from urinary incontinence. It features 44 statements concerning various difficulties that an UI person may go through, the content of fears accompanying the disease, changes in personal and professional life, limitations, compulsion, and sense of control. A low score on the Overall Life Quality scale indicates a low quality of life, concentration on symptoms, a sense of compulsion, control, concessions that the sufferer needs to make, and generally lower well-being. A high score on the Overall Life Quality scale indicates adequate adaptation, well-being, satisfaction, and lack of limitations exerted by the disease. Three main factors are established which explain a variance of $51 \%$. Factor I (Psychological Well-Being) features 18 items, where Cronbach $\alpha=0.967$. Factor II (Physical and Social Well-Being) uses 13 items, where Cronbach $\alpha=0.945$. Factor III (Independence of Symptoms) consists of 5 items, where Cronbach $\alpha=0.829$.

In order to assess the overall quality of life, CASP19 was used, authored by Higgins, Hyde, Wiggins, and Blade (2003). The measure features 19 items, divided 
into 4 subscales: Control, Autonomy, Self-Realisation, and Pleasure.

\section{Results}

\section{Stress coping styles and the quality of life with} a disease

An individual who perceives a disease as a stressful event will attempt to make use of different preventive measures in order to minimize its impact. The effectiveness of activated coping styles by the stress UI women was evaluated by analysing Pearson's correlation.

Our correlation analysis revealed that for the UI patients, the majority of coping styles were negatively correlated with all dimensions of quality of life (TaskOriented Coping, Emotion-Oriented Coping, Diversion), unlike Social Diversion, which correlates positively but statistically insignificantly (Table I).

It was observed that Emotion-Oriented Coping is significantly and negatively correlated with all dimensions of Quality of Life in women suffering from UI. For Psychological Well-Being, the correlation was $r=-0.41$, $p \leq 0.01$; for Physical and Social Well-Being $r=-0.32$, $p \leq 0.01$; for Independence from Symptoms $r=-0.24$, $p \leq 0.05$; and for Overall Quality of Life the correlation was $r=-0.37, p \leq 0.01$. This suggests that EmotionOriented Coping co-occurs with lowered Psychological Well-Being of UI patients, entailing a decreased quality of their life.
Task-Oriented Coping proved statistically significant and negatively correlated with Independence from Symptoms $(r=-0.29, p \leq 0.05)$. This means that by choosing Task-Oriented Coping, a woman with UI reduces her distance to the disease. While trying to solve the problem, she focuses her attention on the symptoms, experiencing stress due to the ineffectiveness of her attempts as well as the specificity of the symptoms (uncontrollable character of the disease).

Avoidance-Oriented Coping turned out to be statistically insignificant for any of the dimensions of quality of life. Only a subtype of Avoidance-Oriented Coping, Distraction, correlated significantly, negatively with the global score of life quality: $r=-0.23$ with $p \leq 0.05$, but the correlation was weak. It appears that women who are more likely to employ distraction attain lower scores on Overall Quality of Life, a quality which is affected by the disease (see Table I).

\section{Stress coping styles and quality of life}

Table II presents coefficients of correlation between ways of coping stress and dimensions of life quality in women tested using CASP-19 scale.

Task-Oriented Coping proved to be significantly and negatively correlated with Control (a component of Quality of Life), $r=-0.33$, with $p \leq 0.01$. This correlation suggests that the use of Task-Oriented Coping by UI women co-occurs with a sense of weaker control over various life events. At the same time, Task-Orient-

Tab. I. Pearson correlation coefficients between Urinary Incontinence Life Quality Scale and Coping Inventory for Stressful Situations (CISS)

\begin{tabular}{lcccc}
\hline & $\begin{array}{c}\text { Psychological } \\
\text { Well-Being }\end{array}$ & $\begin{array}{c}\text { Physical and Social } \\
\text { Well-Being }\end{array}$ & $\begin{array}{c}\text { Independence from } \\
\text { Symptoms }\end{array}$ & $\begin{array}{c}\text { Overall Quality } \\
\text { of Life }\end{array}$ \\
\hline Task-Oriented Coping & -0.15 & -0.06 & $-0.20^{*}$ & -0.13 \\
\hline Emotion-Oriented Coping & $-0.41^{\star *}$ & $-0.32^{\star *}$ & $-0.24^{*}$ & $-0.37^{\star *}$ \\
\hline Avoidance-Oriented Coping & -0.07 & -0.09 & -0.08 & -0.14 \\
\hline Distraction & -0.18 & -0.17 & -0.18 & $-0.23^{*}$ \\
\hline Social Diversion & 0.10 & 0.06 & 0.09 & 0.06 \\
\hline
\end{tabular}

Tab. II. Pearson's correlation coefficient $(r)$ between the CASP-19 scale and Coping Inventory for Stressful Situations (CISS) measures

\begin{tabular}{lcccc}
\hline & Control & Autonomy & Pleasure & \multicolumn{2}{c}{ Self-Realisation } \\
\hline Task-Oriented Coping & $-0.33^{* *}$ & $0.20^{*}$ & $0.29^{\star *}$ & $0.24^{*}$ \\
\hline Emotion-Oriented Coping & $0.23^{*}$ & 0.10 & $-0.21^{*}$ & $-0.24^{*}$ \\
\hline Avoidance-Oriented Coping & -0.11 & 0.17 & 0.03 & 0.06 \\
\hline Distraction & 0.03 & 0.10 & -0.13 & -0.07 \\
\hline Social Diversion & $-0.20^{*}$ & 0.13 & $0.20^{*}$ & 0.16 \\
\hline${ }^{*} p \leq 0.05,{ }^{* *} p \leq 0.01$ & & & &
\end{tabular}


ed Coping happened to be positively correlated with Pleasure (a component of Quality of Life) with $r=0.29$ ( $p \leq 0.01)$, Autonomy $(r=0.20, p \leq 0.05)$, and Self-Realisation $(r=0.24, p \leq 0.05)$. Such scores imply that a frequent use of Task-Oriented Coping is associated with positive emotions, pleasure, independence, and a sense of achievement. This stress coping style correlates with a sense of greater control (Control, $r=0.23, p=0.05$ ).

Emotion-Oriented Coping positively correlates with Control $(r=0.23, p \leq 0.05)$ and negatively with Pleasure $(r=-0.21, p \leq 0.05)$, and Self-Realisation $(r=-0.24$, $p \leq 0.05)$, all correlations being statistically significant.

The association between Avoidance-Oriented Coping and any of the dimensions of Quality of Life did not appear to have statistical significance. Only a subtype of this style, i.e. Social Diversion, demonstrated a negative correlation with Control $(r=-0.20, p \leq 0.05)$, but the correlation was weak. This suggests that for $\mathrm{UI}$ patients, more Social Diversion implies a lower score on Control. Seeking social contact correlates positively with Pleasure $(r=0.20 ; p \leq 0.05)$, but the association in this case was weak.

\section{Stress coping styles in groups of women with different levels of quality of life}

The next stage in our analysis was to isolate 3 groups of women with urinary incontinence with regard to their quality of life $(25 \%$ with the highest quality of life, $25 \%$ with the lowest, and $50 \%$ with average quality of life, all based on scores on Overall Quality of Life indicated by Urinary Incontinence Life Quality Scale). The stress coping styles used by individual groups were compared using analysis of variance ANOVA. Table III presents mean values obtained from the CISS questionnaire in the three ranges of patients.

Our comparison made between such groups demonstrated that on the whole, the low-range group achieved higher mean scores for all coping styles than the women from the other groups, with a statistically significant difference $(p=0.01)$ visible on the Emotion-Oriented Coping scale. Here, the highest statisti- cal mean was achieved by the women with the lowest quality of life (low range, $M=49$ ). Significant differences also became apparent between the low-range and mid-range groups (the latter at 42.9), as well as between low-range and high-range groups (the latter at 38.7).

On Avoidance-Oriented Coping - Distraction ( $p \leq$ 0.05), the highest mean was achieved by the women with low quality of life $(M=18.88)$, while a statistically significant difference became visible between the midrange group $(M=18.79, p \leq 0.05)$ and the high-range group $(M=15.85, p \leq 0.05)$.

\section{Discussion}

Incontinent women will take measures to solve their problem by cognitively transforming their situation. Under difficult circumstances, they accept the challenge though continuing concentration on the problem in their situation turns out to be a depressing factor and is associated with a lower quality of their life. The regularity was observed that women whose life has low quality due to the disease display higher mean scores on all scales of stress coping (Task-Oriented, Avoidance-Oriented, and Emotion-Oriented Coping). This observation might be explained in the following way. Women whose life seems to have a higher quality are better adapted to the disease and reconciled with its symptoms. They do not perceive them as threatening, therefore they do not need to make extra effort to combat stress. Another explanation might me the fact that women who use various stress coping styles experience frustration since their efforts focus their attention on the disease symptoms only the nature of which is barely controllable (urine leaking).

Women who are familiar with the diagnosis undertake a number of countermeasures to minimise or eliminate the problems associated with UI. They search for the origin of the disease, they comply with their doctor's recommendations, and they feel the need to gain control of events. The main aim of their actions is to get rid of limitations that UI imposes on their life. How-

Tab. III. Mean values obtained on Coping Inventory for Stressful Situations (CISS) for women of various levels of quality of life

\begin{tabular}{|c|c|c|c|c|c|c|c|c|c|}
\hline \multirow[t]{2}{*}{ CISS } & \multicolumn{2}{|c|}{$\begin{array}{l}\text { Low quality of life } \\
\text { (low range) } \\
\text { Group } 1\end{array}$} & \multicolumn{2}{|c|}{$\begin{array}{c}\text { Average quality of } \\
\text { life (mid-range) } \\
\text { Group } 2\end{array}$} & \multicolumn{2}{|c|}{$\begin{array}{l}\text { High quality of life } \\
\text { (high range) } \\
\text { Group } 3\end{array}$} & \multicolumn{2}{|c|}{ ANOVA } & \multirow{2}{*}{$\begin{array}{c}\text { Statistically } \\
\text { significant } \\
\text { differences } \\
\text { between } \\
\text { groups }\end{array}$} \\
\hline & $M$ & $S D$ & $M$ & $S D$ & $M$ & $S D$ & $F$ & $p$ & \\
\hline Task-Oriented Coping & 55.65 & 10.45 & 54.24 & 8.99 & 49.45 & 9.17 & 2.58 & 0.081 & - \\
\hline Emotion-Oriented Coping & 49.00 & 7.51 & 42.90 & 9.98 & 38.70 & 12.18 & 4.82 & 0.010 & $1-2,1-3$ \\
\hline Avoidance-Oriented Coping & 41.82 & 7.81 & 41.16 & 7.72 & 38.20 & 8.04 & 1.32 & 0.270 & - \\
\hline Avoidance: Distraction & 18.88 & 4.26 & 18.79 & 4.92 & 15.85 & 4.16 & 3.24 & 0.043 & $2-3$ \\
\hline Avoidance: Social Diversion & 14.88 & 4.30 & 14.78 & 3.31 & 14.65 & 4.55 & 0.02 & 0.982 & - \\
\hline
\end{tabular}


ever, excessive concentration on themselves due to the above factors contributes to a sense of lower quality of their life. Authors who deal with the influence of a coping style on the quality of life with oncological disease claim that using a task-oriented coping style, and hence an excessive concentration on the problem, contributes to the increased quality of the sufferer's life [22].

In the case of women with urinary incontinence who employ an emotion-oriented coping style and avoidance-oriented style based on seeking social diversion enjoy life of average or lower quality. Bidzan et al. [8] observed that the emotion-oriented and avoidance-oriented styles involve a high level of neuroticism. A stronger preference for social contact (social diversion) as a way of dealing with stress correlates with a higher quality of life in Szymona-Pałkowska et al.'s study [23], though this trend was not equally pronounced in the presented research. In the opinion of Terelak et al. [22] and Moreau et al. [24], oncological patients also used all of the above styles, particularly those involving avoidance and orientation on emotions. All of this suggests that in difficult moments sufferers are more ready to seek distraction in order to forget about the problem, even for a short while. Terelak et al. [22] stresses that avoidance- and emotion-based styles of coping are more effective than resignation and passive means of fighting stress. Yet these styles do not guarantee increased quality of life. Similar findings are reported by Rzeszutko and Rolińska [25] who studied stress coping styles in a group of multiple sclerosis patients. The study demonstrated that people with disease are less likely to employ strategies focused on solving their problem. The more severe the disability, the greater the concentration on one's internal emotional states. According to Mohr et al. [26], a greater disability resulting from a disease is accompanied by higher depressiveness and the use of less adaptive ways of combating stress, i.e. styles concentrated on emotions and avoidance. McCabe et al. [27] present a similar view. They demonstrate that ill people are less likely to use solution-seeking and support-seeking styles than healthy individuals. They manifest wishful thinking and worse adaptation to their disease. Beatty et al. [28] and Jean et al. [29] point to the fact that during the period of an elevated stress level people are more eager to use a strategy focused on emotions whose aim is to modify the meaning and reinterpretation of a given situation. Palak [30] and Lode et al. [31] believe that people with an elevated level of depression and anxiety display a higher level of neurosis and introversion, and they are less conciliatory and conscientious. Palak [30] claims that a person's stress coping style is largely affected by his or her selfimage. Due to a developing disease, the sufferer can show a tendency towards reserve, distrust, feeling of inferiority, grumpiness, concentration on themselves, emotional instability - all these affecting the choice of a stress coping style. Montel and Bungener [32] stress that better adjustment to disease implies its lower severity, greater concentration on task-oriented styles but lower concentration on avoidance and emotion-oriented styles [33]. These authors also believe that styles oriented towards avoidance and emotions are useful in a situation when the source of stress is not clear and the sufferer finds it hard to plan the efficient action.

\section{Conclusions}

Task-oriented coping is associated with a little distance to the disease (an aspect of quality of life) and low sense of internal control, but it gives a feeling of internal autonomy and self-realisation.

Emotion-oriented coping is associated with low psychological, physical and social well-being, as well as little distance to the disease (indicators of quality of life with disease), lower pleasure, lower self-realisation, but on the whole gives a sense of internal control.

Avoidance-oriented coping does not correlate significantly with any of the dimensions of either quality of life with disease and overall quality of life. Seeking social diversion (a form of avoidance) correlates with a low sense of control but greater pleasure.

The most used stress coping style used by the UI women was task-oriented coping, and this style yielded similar levels in the three studied groups, irrespective of perceived quality of life.

Emotion-oriented coping had the greatest differentiating force in the three groups.

An intensive use of various stress coping styles takes its toll on the quality of life with disease, but can yield a higher quality of life in other spheres of life, i.e. self-realisation, pleasure, or autonomy. Urinary incontinence involves uncontrollable urine loss, and this situation forces women either to reconcile with the symptoms and learn to live with them or concentrate on them, whereby their emotional state will be affected, leading to a lowered quality of their life.

\section{Disclosure}

Authors report no conflict of interest.

\section{References}

1. Mladenović-Segedi L, Segedi D, Parezanović-llić K. Quality of life in women with urinary incontinence. Medicinski Glasnik 2011; 8 (Suppl 2): 237-242.

2. Radziszewski P, Dobroński P. Nietrzymanie moczu. Wydawnictwo Lekarskie PZWL, Warszawa 2008.

3. Starczewski A, Brodowska A, Brodowski J. Epidemiologia i leczenie nietrzymania moczu oraz obniżenia narządów miednicy u kobiet. Polski Merkuriusz Lekarski 2008; 25 (Suppl 145): 74-76.

4. Rechberger T, Miotła P, Skorupski P, et al. The quality of life of patients with overactive bladder after local injections of botulinum toxin A a preliminary report. Gin Pol 2010; 81: 24-30. 
5. Opara J, Socha T, Bidzan M, et al. Stress urine incontinence especially in elite women athletes extremely practicing sports. Archives of Budo 2011; 7: 227-231.

6. Withagen M, Miliani A. Which factors influenced the result of a tension free vaginal tape operation in a single teaching hospital? Acta Obstet Gynecol Scand 2007; 86 (Suppl 9): 1136-1139.

7. Bidzan M, Smutek J, Garstka-Namyst K, et al. A multi-disciplinary perspective on the diagnosis and treatment of urinary incontinence. In Urinary Incontinence. Alhasso A, Fernando A (red.). In Tech, Rijeka 2012 41-58.

8. Bidzan M, Bidzan L, Smutek J. A model of psychological factors conditioning health related quality of life in urodynamic stress incontinence patients after TVT. In: Urinary Incontinence. Alhasso A, Fernando A (eds.). In Tech, Rijeka 2012; 131-144

9. Bidzan M, Smutek J, Bidzan L. Psychosexual biography and the strategies used by women afflicted with stress urinary incontinence during intercourse: two case studies. Med Sci Monit 2010; 16: CS6-10.

10. Bidzan M, Smutek J. Strategies for coping with stress urinary incontinence in women. Acta Neuropsychologica 2009; 7: 131-138.

11. Heszen I. Kliniczna psychologia zdrowia. In: Psychologia kliniczna. Sęk H (red.). PWN, Warszawa 2006

12. Lazarus R, Folkman S. Stress Appraisal and Coping. Springer, New York 1984.

13. Frank RG, Umlauf R, Wonderlich $\mathrm{S}$, et al. Differences in coping styles among persons with spinal cord injury: a cluster analytic approach. Journal of Consulting and Clinical Psychology 1987; 55: 727-731.

14. Harkins S, Elliott T, Wan T. Emotional distress and urinary incontinence among older women. Rehabilitation Psychology 2006; 51 (Suppl 4): 346-355.

15. Revenson T, Felton B. Disability and coping as predictors of psychological adjustment to rheumatoid arthritis. Journal of Consulting and Clinical Psychology 1989; 57: 344-348.

16. Opara J, Czerwińska-Opara WE. The prevalence of stress urinary incontinence in women studying nursing and related quality of life. Prz Menopauzalny 2014; 13: 32-35.

17. Lee H, Yoon J, Jeong Y. The effects of personal resources and coping strategies on depression and anxiety in patients with chronic obstruc tive pulmonary disease. Heart \& Lung: The Journal Of Critical Care 2013, 42 (Suppl 6): 473-479.

18. World Health Organization Quality of Life (WHOQOL) Group (1997) WHOQOL measuring quality of life: The World Health Organization quality of life instruments. WHO/MSA/MNH/ PSF/97.4. Retrieved from: http://www.who.int/mental_health/media/en
19. Strelau J, Jaworowska A, Wrześniewski K, Szczepaniak P. Kwestionariusz Radzenia Sobie w Sytuacjach Trudnych CISS. Podręcznik. Pracownia Testów Psychologicznych Polskiego Towarzystwa Psychologicznego, Warszawa 2005

20. Higgs P, Hyde M, Wiggins R, Blade D. Researching Quality of Life in Early Old Age: The Importance of Sociological Dimension. Social Policy \& Administration 2003; 37 (Suppl 3): 239-252.

21. Szymona-Pałkowska K, Janowski K, Kraczkowski JJ, et al. Quality of life in women with urinary incontinence. In: The multidisciplinary approach to health and disease: selected papers. Janowski K, Steuden S (red.). CPPP Scientific Press, Lublin 2011; 100-111.

22. Terelak J, Krzesicka E, Małkiewicz M. Poczucie umiejscowienia kontroli i poczucie koherencji a strategie rdzenia sobie ze stresem $u$ kobiet chorych na raka piersi. Instytut Psychologii. Uniwersytet Kardynała Stefana Wyszyńskiego w Warszawie, Warszawa 2009; 9, 21-44.

23. Szymona-Pałkowska K, Kraczkowski JJ, Janowski K, et al. Selected determinants of quality of life in women with urinary incontinence. Prz Menopauzalny 2014; 13: 84-88.

24. Moreau T, Schmidt N, Joyeux O, et al. Coping strategy and anxiety evolution in multiple sclerosis patients initiating interferon-beta treatment. Eur J Neurol 2009; 62 (Suppl 2): 79-85.

25. Rzeszutko E, Rolińska A. Radzenie sobie ze stresem u chorych na stwardnienie rozsiane. Curr Probl Psychiatry 2011; 12: 293-300.

26. Mohr D, Goodkin D, Gatto N, Wende J. Depression, coping and level of neurological impairment in multiple sclerosis. Mult Scler 1997; 3: 254-258.

27. McCabe M, McKern S, McDonald E. Coping and psychological adjustment among people with multiple sclerosis. J Psychosom Res 2004; 56 : 335-361.

28. Beatty W, Hames K, Blanco C, et al. Correlates of coping style in patients with multiple sclerosis. Mult Scler 1998; 4: 440-443.

29. Jean V, Beatty W, Paul R, Mullins L. Coping with general and diseaserelated stressors by patients with multiple sclerosis: relationships to psychological distress. Mult Scler 1997; 3: 191-196.

30. Palak Z. Samoakceptacja jako jeden z czynników warunkujących funkcjonowanie jednostki. Ann UMCS Sect J 1995; 8: 23-31.

31. Lode K, Brue E, Klevan G, et al. Coping with multiple sclerosis: a 5-year follow-up study. Acta Neurologica Scandinavica 2010; 122: 336-342.

32. Montel S, Bungener C. Coping and quality of life in one hundred and thirty five subjects with multiple sclerosis. Mult Scler 2007; 13: 393-401.

33. Banach R, Zdziennicki A. Diagnostyka i aktualne wytyczne postępowania terapeutycznego w nietrzymaniu moczu u kobiet. Ginekologia Praktyczna 2004; 12: 37-43. 